\title{
A construção da competência clínica: \\ da concepção dos planejamentos de ensino às representações da aprendizagem entre graduandos de enfermagem
}

\author{
The building of clinical competence: from the concept of planning teaching to the \\ expression of learning among nursing graduate students
}

Pensar a formação de enfermeiros pressupõe articular essa questão às expressões de referenciais teóricos, na perspectiva de uma vertente pedagógica que passe pelo construtivismo e por competências. Assim, os objetivos foram: caracterizar, numa visão longitudinal, a proposição de competências assistenciais na graduação; identificar o potencial de competência clínica de graduandos de enfermagem; analisar representações discentes relativas à aprendizagem das experiências clínicas $e$ propor referenciais para a construção da competência clínica no âmbito da graduação em enfermagem. $O$ estudo foi de natureza qualitativa, tendo como sujeitos alunos do último semestre da graduação, num total de 29 participantes; foi realizada análise documental dos planos de ensino das disciplinas assistenciais da graduação $e$ utilizou-se também a Técnica do Incidente Crítico (TIC), proposta por Flanagan, como estratégia metodológica apta a identificar experiências significativas para a aprendizagem clínica. A instituição de ensino $e$ os sujeitos aceitaram participar do estudo, conforme as recomendações ético-legais. Os dados foram trabalhados segundo a análise de conteúdo de Bardin, e evidenciaram: uma organização curricular centrada em disciplinas, com modalidades organizativas que partem do genérico para o específico, mantendo lógicas internas aparentemente refratárias às organizações somativas; uma direção da aprendizagem voltada à execução metódica de práticas em evolução, escolhidas pelos docentes, estimulando a inserção discente em programações pré-estabelecidas e reiterativas. A ligação das atividades de ensino à vida real se faz por meio de práticas em campo que respondem timidamente à problematização da realidade. As intervenções parecem ser privilegiadas segundo uma ordem externa, as vezes distante da realidade dos alunos. Emergem, também, sinalizações de uma aprendizagem com vínculos pouco substantivos entre os conhecimentos prévios e a potencialização do julgamento crítico e do raciocínio clínico. Como proposição, o estudo trouxe reconsiderações para o processo ensinoaprendizagem e a influência da concepção construtivista na proposição das competências clínicas.

Magda Cristina Queiroz Dell'Acqua Tese de Doutorado, 2004 Programa de Pós-Graduação em Saúde do Adulto, Faculdade de Enfermagem, Universidade de São Paulo, São Paulo. <mqueiroz@fmb.unesp.br>

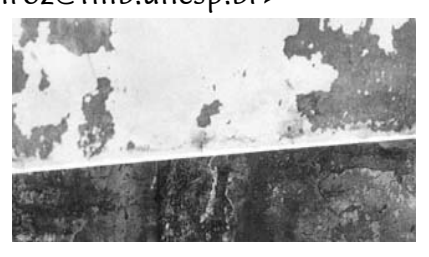

PALAVRAS-CHAVE: Educação em enfermagem; educação baseada em competências; competências profissionais; prática profissional; construtivismo.

KEY WORDS: Nursing education; competence-based education; professional competence; professional practice; constructivism.

PALAVRAS CLAVE: Educación en enfermería; educación basada en competencias; competencia profesional; práctica profesional; construtivismo.

Recebido para publicação em 19/07/04. Aprovado para publicação em 27/07/04. 